\title{
ФУНКЦІЇ ТА ПРИНЩИПИ КАДРОВОї РОБОТИ В СУДОВІЙ СИСТЕМІ
}

\author{
ШЕВЧЕНКО АнНа Василівна - кандидат юридичних наук, суддя Київського \\ окружного адміністративного суду
}

DOI:10.32782/NP.2020.1.5

УДК 342.9

У статті визначено поняття функиій та принципів кадрової роботи в судовій системі. Принципи визначені як керівні засади та ідё̈, що відображають синергію дiяльності із кадрового менеджменту у сбері судового адміністрування та положень законодавчих, підзаконних нормативних актів, які спрямовані на формування високоякісного суддівсъкого корпусу та апарату органів, що забезпечують здійснення правосуддя.

Функиіями кадрової роботи судових органів розуміються напрямки роботи 3 кадрами (персоналом) судових органів, що виражанться у процесах пробесійноӥ орієнтації, прогнозування $i$ планування кадрових потреб, добору, підготовки та розстановки кадрів.

При визначенні змісту приниипів кадрової роботи в судовій системі та їх видів необхідно виходити із декількох важливих аспектів: (1) дуалістична публічна природа сутності приниипів; (2) високі вимоги до професіоналізму, поведінки та високий рівень відповідальності потребують відповідного високоякісного кадрового обслуговування, що відображається на принципах роботи органів та інституиій, які виконують кадрові бункиіи; (3) на відміну від сбери публічного адміністрування, у якій кадрові процеси є $\dddot{\imath}$ частиною, кадрова діяльність в судах не пов'язана зі здійсненням правосуддя.

Загально-правові приниипи кадрової роботи спрямовані на забезпечення системи судового адміністрування висококвалібікованими кадрами, їх професійного зростання. До таких принципів можна віднести: законність; верховенство права; рівність; гласність; публічність; неупередженість (недопустимість існування конфлікту інтересів). Зазначені принципи характеризують універсальне правове бачення не тільки працівників кадрових підрозділів, а й напрямків кадрових фбункцій. Реалізачія загально-правових приниипів має спільну природу для будв-якого прачівника судових органів, незалежно від того, здійснюе він правосуддя, чи створюе умови для роботи cуддi.

Ключові слова: приниипи, кадрова робота, судова система, підготовка суддів, професійна квалібікаизі, гласність, рівність.

Важливими завданнями судової реформи є підготовка та впровадження організаційно-правових засад діяльності органів судової влади, спрямованих на підвищення ефективного використання кадрового потенціалу суду, вироблення дієвих методів оцінювання якості надання судових послуг, регламентація прав і відповідальності працівників суду, визначення рівня їх професіоналізму, тому важливим 6 розуміння функцій кадрової роботи судових органів та принципів, на яких вона базується [1, c. 176].

Поняття функцій та принципів в теорії юриспруденції досліджували С.С. Алексєєв, О.В. Зайчук, М.С. Кельман, А.М. Ко- 
лодій, А.С. Піголкін, О.В. Петришин, П.М. Рабінович, О.Ф. Скакун, Ю.О. Тихомиров, М.В. Цвік та інші. Адміністративноправову характеристику зазначених понять розглядали у своїх роботах: В.Б. Авер'янов, Г.В. Атаманчук, Ю. П. Битяк, І.П. Голосніченко, Є.В. Додін, Т.Є. Кагановська, С.В. Ківалов, Т.О. Коломоєць, В.К. Колпаков, О.В. Кузьменко, М.Г. Мельник, В.Н. Протасов, В. Д. Сорокин, С.Г. Стеценко та інші.

Мета статті полягає в з'ясуванні змісту та видів функцій, а також принципів кадрової роботи в судовій системі.

\section{Виклад основного матеріалу}

Термін «функція» має багатоманітність значень: 1) явище, яке залежить від іншого явища, є формою його виявлення і змінюється відповідно до його змін; 2) призначення, роль чого-небудь [2, с.653]. В теорії права під функціями розуміють - основні напрямки впливу явища на суспільні відносини, в яких розкривається сутність цього явища.

Можна говорити про те, що функції кадрової роботи судів є як проявом функцій роботи судів взагалі, так і управління в судових органах.

Провідні спеціалісти у галузі судового адміністрування пропонують таку класифікацію функцій судового кадрового менеджменту: планування, організація, робота 3 кадрами, керівництво, контроль[3]. Представлена класифікація функцій судового кадрового менеджменту стала основою багатьох досліджень, хоча до неї було внесено чимало доповнень, уточнень та змін[1, с.180]. На думку Л. Д. Оліфіренко, кадровий менеджмент суду охоплює не тільки функції, що традиційно пов'язуються 3 кадровою роботою, а й знання, навички та здібності, завдяки яким персонал суду моделює принципи фахової поведінки, зокрема: результативність, продуктивність, індивідуалізацію результатів та врахування довгострокової перспективи під час прийняття рішень 3 кадрового менеджменту суду [4], [5].
Під функціями кадрового роботи судових органів ми розуміємо напрямки роботи 3 кадрами (персоналом) судових органів, що виражаються у процесах професійної орієнтації, прогнозування і планування кадрових потреб, добору, підготовки та розстановки кадрів. Ознаками функцій кадрової роботи у судових органах $є$ :

1) мають об'єктивно-суб'єктивний характер - об'єктивність означає їх обумовленість закономірностями взаємодії суспільства і держави, а суб'єктивність вказує на те, що вони реалізуються завдяки свідомості і волі людей, задіяних у кадровій роботі;

2) мають державно-владний характер, тому що посадові особи. які здійснюють функції кадрової роботи, наділенні державно-владними повноваженнями;

3) мають управлінський характер, тому що є проявом управлінської діяльності;

4) обумовлені цілями й завданнями управління;

5) мають безперервний характер тобто це усталена предметна діяльність, що означає їх постійний характер на тривалому періоді існування держави.

З погляду I.О. Русанової та I.В. Юревич судовому кадровому менеджменту притаманні наступні функції 1) вивчення ринка праці, відбір, призначення та прийом персоналу; 2) ділова оцінка персоналу при прийнятті, атестації, доборі та розстановці кадрів; 3) визначення заробітної плати і пільг, оформлення трудового контракту; 4) організація праці, розробка посадових інструкцій; 5) дотримання етики ділових відносин і корпоративної культури; 6) управління конфліктами і стресами; 7) оцінка трудової діяльності, навчання, підвищення кваліфікації і перепідготовка кадрів; 8) планування ділової кар'єри і управління службово-професійним зростанням; 9) управління нововведеннями у кадровій роботі; 10) управління поведінкою персоналу, дотримання дисципліни праці; 11) звільнення персоналу [6].

Таким чином підтримуючи думки вищезазначених вчених, можна виділити наступні функції кадрової роботи в судах, враховуючи особливості здійснення правосуддя: 


\section{$=$ Адміністративне право}

1) підбір кадрів - тобто комплектування судових органів висококваліфікованими фахівцями. У теорії управління під підбором кадрів розуміють процес установлення придатності кандидатів і вибір із них найбільш підготовлених для ефективного виконання функціональних обов'язків. Головними завданнями при цьому вважають: забезпечення об'єктивності при підборі кадрів; установлення певних механізмів для гарантування прозорості і демократичності процесу; визначення загальних кваліфікаційних вимог для бажаючих обійняти посаду; чітке регулювання порядку проведення конкурсу (від оголошення про вакансію до призначення на посаду за його результатами) [7, с.60]. Зміст процедури добору кадрів становлять аналіз та оцінка особистісних якостей претендента, а також формулювання висновку про ступінь його відповідності вимогам конкретної посади [8, с. 24]. Так, сутність процедури добору кандидата на посаду судді місцевого суду полягає у виборі особи, яка $є$ найбільш придатною для здійснення функцій судової влади у сфері публічно-правових відносин;

2) аналіз стану роботи з відбору, розстановки, зміцнення та збереження професійних кадрів;

3) планування потреб судових органів - виражається у прогнозуванні кількості вакантних посад, встановленні критеріїв оцінки роботи, дозволяє більш чітко формулювати цілі діяльності судової установи та використовувати систему показників, що необхідна для подальшого контролю результатів, забезпечує більш чітку координацію зусиль структурних підрозділів апарату суду, що у свою чергу має зміцнити взаємодію керівників цих підрозділів та керівника апарату суду[9, с. 280];

4) організація роботи суду полягає в тому, що вона формує структуру судової установи, а також забезпечує усім необхідним для іiї функціонування - персоналом, матеріалами, устаткуванням, приміщеннями, грошовими коштами;

5) контроль - це процес забезпечення досягнення цілей організації, який необхідний для з'ясування і вирішення кадрових проблем.
Підгрунтям моделювання процесу якісного кадрового забезпечення, що стосується як судів як основної ланки системи органів судової гілки влади, так й інших структурних складових цієї системи $є$ принципи [10, с. 170].

При всій багатоманітності визначень принципів права науковці одностайні в тому, що принципи права - це ідеї, засади, положення, які обумовлені об'єктивними закономірностями розвитку суспільства, розкривають сутність права як регулятора суспільних відносин, міри справедливості, рівності й свободи з метою досягнення правопорядку.

Загальноприйнятим є поділ принципів права на загальні, галузеві, міжгалузеві та принципи інститутів права. Загальними принципами права є орієнтири, за якими діє вся правова система держави. Галузеві принципи - це керівні ідеї, на яких базуються окремі галузі права. Міжгалузеві принципи визначають засади двох або більше галузей права. Принципи інститутів права - це керівні ідеї, на яких базуються інститути галузей права.

На думку А. Д. Оліфіренко кадровий менеджмент суду, як складний, багатосторонній та специфічний аспект судової влади, грунтується на основоположних принципах державного управління, закладених у нормах адміністративного права, зокрема, принципах єдності та оперативної самостійності у прийнятті рішень, відповідальності за їх результати [1, с. 177].

Слушною є думка Т. E Кагановської, що принципи кадрового забезпечення державної служби повинні знайти свій прояв:

- у нормах адміністративного права, що утворюють та регламентують діяльність органів державної влади, органів місцевого самоврядування та їх посадових осіб. Зокрема на тісний взаємозв'язок принципів державної служби з принципами адміністративного права, яке суттєво впливає на регулювання державно-службових відносин, а також $з$ принципами управління (державного управління), яке, в свою чергу, впливає на формування системи принципів адміністративного права, вказує Ю. П. Битяк [11, с. 11-12]. 
- в адміністративному законодавстві, яке є зовнішньою формою прояву адміністративно-правових норм;

- в управлінських правовідносинах, які є формою реалізації повноважень суб'єктів кадрового забезпечення [12, с. 33].

Підсумовуючи, можна сказати, що принципи кадрової роботи судів - це обумовлені об'єктивним розвитком суспільних відносин, закріплені у нормативноправових актах беззаперечні вимоги, які відображають сутність кадрового забезпечення судів, визначають його форми й методи, покликані реалізувати судами функції держави, що виражаються у здійсненні правосуддя, захисті прав, свобод людини й громадянина.

3 огляду на викладене, можна визначити ознаки, які притаманні принципам кадрового забезпечення судів:

1) є керівними ідеями, беззаперечними вимогами, засадами, на яких базується кадрова робота судів;

2) обумовлені об'єктивним розвитком суспільних відносин, тобто залежать від реально існуючих політичних, економічних, ідеологічних відносин, що склалися у суспільстві та впливають на роботу державних органів взагалі та роботу органів суду зокрема;

3) закріплені в нормативно-правових актах, тобто набувають значення загальних правил поведінки, які мають загальнообов'язковий, владний характер;

4) відображають сутність кадрового забезпечення суду демократичної держави;

5) визначають форми й методи кадрового забезпечення судів для досягнення ефективної роботи органів суду;

6) їх мета - реалізація судовими органами функцій із здійснення правосуддя, захисту прав і свобод людини і громадянина.

Отже, можна запропонувати розподіл принципів кадрової роботи судів 1) загальні принципи - це принципи, що є системою координат в межах яких діють правові явища в державі, і виходять із загальних принципів права, 2) загально-управлінські, на яких базується управлінська діяльність, 3) спеціально-управлінські - на яких базується кадрова робота.
До загальних принципів можна віднести: верховенство права, законність, гуманізм, рівність, демократизм.

1) Принцип верховенства права, закріплений у статті 8 Конституції України як загально правовий принцип. Він передбачає, що Конституція України має найвищу юридичну силу, а закони та інші нормативно-правові акти приймаються на основі Конституції України і повинні відповідати їй.

2) Принцип законності закріплений ст. 19 Конституції України, у відповідності до якої його зміст полягає у тому, що органи державної влади, місцевого самоврядування, їх посадові особи зобов’ язані діяти лише на підставі і в межах повноважень та у спосіб, що передбачений Конституцією та законами України. В діяльності судів це означає що: суд і суддя при винесенні рішення діють на підставі спеціально дозвільного принципу правового регулювання - «заборонено все крім того, що прямо дозволено законом», а громадяни та об'єднання громадян можуть діяти на підставі загально дозвільного принципу - «дозволено все крім того, що прямо не заборонено в законі».

3) Принцип гуманізму, передбачений ст. 3. Конституції України, встановлює, що людина, її життя і здоров’я, честь і гідність, недоторканність і безпека визнаються в Україні найвищою соціальною цінністю. Права і свободи людини та їх гарантії визначають зміст і спрямованість діяльності держави. Держава відповідає перед людиною за свою діяльність. Утвердження і забезпечення прав і свобод людини є головним обов'язком держави .

4) Принцип рівності означає, що всі особи, незалежно від статі, майнового становища, національності, віросповідання однаково захищаються законом, і в той же час несуть однакову відповідальність перед законом.

5) Принцип демократизму виражається в тому, що в демократичній державі право виражає волю народу. Закони приймаються парламентом, який обирається через безпосередню форму демократії - вибори.

Друга група принципів - це вимоги, які висуваються до управлінської діяльності. 


\section{Адміністративне право}

До них належать:

1) наукова обгрунтованість означає важливість і значимість систематизованих наукових знань про управління, які дозволяють своєчасно та якісно управляти поточною діяльністю організації, прогнозувати можливі варіанти розвитку подій і у відповідності до цього розробляти стратегію і тактику функціонування, грамотно реалізовувати постановку цілей і задач;

2) комплексність передбачає поширеність на всі сфери кадрової політики, тобто на орієнтацією управління персоналом на законодавство про працю, забезпеченням умов для стабілізації кадрового складу та мінімізації звільнень; облік поточної та перспективної потреби організації в персоналі; додержання балансу інтересів організації та ії працівників; залучення до співробітництва при реалізації кадрової політики всіх заінтересованих сторін; максимальна турбота про кожну людину окремо, повага iї прав та свобод;

3) системність означає поширеність найбільш значущій комплекс взаємопов'язаних і взаємообумовлених підсистем, наприклад, «підсистема безстрокового призначення», «підсистема підвищення кваліфікації працівників апарату суду», «підсистема репутації», «підсистема оплати праці», що взаємодоповнюють одна одну та забезпечують, серед іншого, мотивування персоналу;

4) ефективність здійснення судового кадрового менеджменту полягає в тому, що будь-які затрати на всі заходи та процеси щодо добору та призначення працівників судової системи повинні окупатися через ефективні результати їх діяльності. Розробки менеджменту націлені на те, щоб працівники використовували весь потенціал, всі можливості для підвищення продуктивності та якості роботи, щоб були зацікавленими у максимальній ефективності та оперативності роботи судової установи;

5) єдність має забезпечуватися однаковою кадровою політикою для працівників суду, починаючи від підходів до підбору та розстановки кадрів, та до максимальної турботи про кожного працівника окремо, поваги його прав та свобод [9, с.278].
До третьої групи принципів, що визначають засади кадрової роботи, належать: 1) принцип рівного доступу до служби полягає у тому, що громадяни України незалежно від походження, соціального і майнового стану, расової і національної приналежності, статі, політичних поглядів, релігійних переконань, які одержали відповідну освіту і професійну підготовку та пройшли у встановленому порядку конкурсний відбір, або за іншою процедурою передбаченою чинним законодавством мають право обіймати посади у суді;

2) принцип фаховості виражається у тому, що особа, яка претендує на посаду працівника суду повинна мати відповідну освіту й професійну підготовку;

3) принцип політичної неупередженості $є$ підкріпленням принципу професіоналізму без врахування політичних переконань; державні службовці мають неупереджено, своєчасно виконувати свої службові обов'язки незалежно від своїх політичних поглядів й переконань;

4) принцип універсальності полягає у застосуванні однакових підходів до всіх учасників відносин в сфері кадрового забезпечення;

5) принцип конкуренції забезпечує авторитетність професії [13, с. 39].

\section{Мітература}

1. Оліфіренко Л. Д. Роль кадрового менеджменту в механізмі судового адміністрування в умовах реформування судової системи України. Проблеми і перспективи економіки та управління. 2015. № 3. C. $176-185$.

2. Словник української мови: в 11 тт. / АН УРСР. Інститут мовознавства; за ред. I. К. Білодіда. Київ, 1970-1979. Т. 10. С. 653

3. Сабадош Г. О. Адміністративнодержавний менеджмент як інструмент реорганізації системи державного кадрового забезпечення. Державне управління : удосконалення та розвиток. 2014. № 4. URL: http://www.dy.nayka.com.ua/.

4. Шевченко О. М. Структура і зміст комунікативної компетентності державних службовців. Историко-правовые, социально-экономические и технологические 
аспекты развития общества : материалы докладов Междунар. науч.-практ. конф. (г. Чернигов, 25 марта 2015 года). Чернигов, 2015. С. 124.

5. Olifirenko L. Organizational Development of Public-Private Partnerships. Ukraine - EU. Modern technology, business and law : collection of international scientific papers : in 2 part. Part 1. : Modern priorities of economics, management and social development. Environmental protection collection. Chernihiv : CNUT, 2015. P. 32-33.

6. Кадровий менеджмент [Електронний ресурс]. Режим доступу: http://www. upravlenie24.ru/kadrmanagment.htm.

7. Прилуцький С. В. Формування корпусу професійних суддів України : дис. ... кандид. юрид. наук : 12.00.10. Київ, 2003. 223 c.

8. Слепенков И. М. Основы теории социального управления : учеб. пособие Москва, 1990. 301 с.

9. Русанова I.О., Юркевич I.В. Деякі питання судового кадрового менеджменту. Форум права. 2016. № 4. С. 277-281.

10. Мельник М. Г. Класифікація принципів кадрового забезпечення діяльності органів судової гілки влади. Держава та регіони. Серія Право. 2011. № 2. С. 171-175.

11. Битяк Ю. П. Державна служба в Україні: проблеми становлення, розвитку та функціонування: автореф. дис. докт. юрид. наук: 12.00.07. Харків, 2006. 36 с.

12. Кагановська Т. Е. Кадрове забезпечення державного управління в Україні: Монографія. Харків, 2010. 330 с.

13. Зозуля В. О. Принципи кадрового забезпечення органів державної влади. Економіка та держава. Серія державне управління. 2017. № 2. С. 38-40.
The article defines the concept of functions and principles of personnel work in the judicial system. The principles are defined as guiding principles and ideas, reflecting the synergy of human resource management activities in the field of judicial administration and provisions of legislative, bylaw normative acts aimed at forming a high-quality judicial body and apparatus of the bodies providing justice.

The functions of the judicial work of the judiciary are understood as the directions of work with the personnel (staff) of the judicial bodies, which are expressed in the processes of professional orientation, forecasting and planning of personnel needs, selection, training and placement of personnel.

In determining the content of the principles of personnel work in the judiciary and their types, it is necessary to proceed from several important aspects: (1) the dualistic public nature of the essence of the principles; (2) high requirements for professionalism, behavior and a high level of responsibility require appropriate high-quality staffing, which is reflected in the principles of the work of bodies and institutions that perform human resources functions; (3) Unlike public administration, in which staffing processes are part of it, staffing in the courts is not related to the administration of justice. The general principles of human resources work are aimed at providing the judicial administration system with highly qualified personnel, their professional growth. These principles include: legality; Rule of Law; equality; publicity; publicity; impartiality (inadmissibility of conflict of interest). These principles characterize the universal legal vision not only of employees of human resources, but also areas of human resources functions. The implementation of the general principles of law is of a common nature for any judicial officer, regardless of whether he or she administers justice or creates the conditions for a judge to work.

Keywords: principles, personnel work, judicial system, training of judges, professional qualification, publicity, equality. 